\title{
PELATIHAN PENCATATAN KEUANGAN DAN ANALISA KEUANGAN SEDERHANA PADA PETERNAK AYAM PETELUR DI DESA YANGAPI
}

\author{
I Nyoman Arta Yasa1) \\ 1)Manajemen Keuangan, Fakultas Ekonomi dan Bisnis, Universitas Pendidikan Nasional, Denpasar, Bali, \\ Indonesia \\ Corresponding author : I Nyoman Arta Yasa \\ E-mail : artakomang603@gmail.com
}

Diterima 12 Maret 2021, Direvisi 03 April 2021, Disetujui 03 April 2021

\begin{abstract}
ABSTRAK
Pencatatan transaksi sesuai standar akuntansi bertujuan untuk memungkinkan adanya penilaian dan pengambilan keputusan yang jelas dan tegas bagi pihak yang menggunakan informasi tersebut. Keputusan yang bersifat keuangan merupakan implementasi nyata terhadap keberlanjutan sebuah unit bisnis yang dijalankan. Pencatatan transaksi dengan standar akuntansi akan menghasilkan laporan keuangan yang nantinya dapat membantu pengambilan keputusan. Pengabdian kepada masyarakat ini bertujuan untuk memberikan pemahaman pencatatan transaksi keuangan dan penilaian kinerja keuangan unit bisnis pada peternak ayam ras petelur di Desa Yangapi. Metode kegiatan yang dilakukan adalah : Kegiatan I. Melakukan diskusi dengan peternak di Desa Yangapi untuk mengidentifikasi kebutuhan peternak terhadap laporan keuangan. Kegiatan II. Pelatihan pencatatan akuntansi dan pemahaman analisa rasio keuangan. Kegiatan III. Evaluasi terhadap laporan keuangan peternak. Peserta pelatihan berjumlah 6 orang. Hasil dari kegiatan memberikan pengaruh positif yang dipersentasikan dari $53,33 \%$ menjadi $67,67 \%$ dalam memehami pecatatan secara akuntansi dan analisa keuangan sederhana. Kesimpulan ada pengaruh pelatihan pencatatan keuangan dan analisa keuangan sederhana terhadap pengambilan keputusan peternak ayam ras petelur di Desa Yangapi.
\end{abstract}

Kata kunci: akuntansi; analisa rasio keuangan; pengambilan keputusan.

\begin{abstract}
Recording transaction in accordance with accounting standard aims to allow for the assessment and decision making clear and firm for those who use that information. Decisions that are financial in nature are real implementations of the sustainability of a business unit being run. Recording transactions based on the accounting standards will produce financial reports that could help make decisions later on. This community service aims to provide understanding of recording financial transactions and assessing the financial performance of business units for laying breed chicken breeders in Yangapi Village. The method of activities conducted is as follows: Activity I. Conducting the discussions with breeders at Yangapi Village to identify the need of breeders for financial reporting. Activity II. To formulate the breeders' need regarding to financial report. Activity III. Provide training in accounting record and understanding of financial ratio analysis. Activity IV. To do an evaluation to the breeders' financial reports. There were 6 participants included. The results of these activities have a positive effect with the percentage of $53.33 \%$ to $67.67 \%$ in understanding accounting records and simple financial analysis. The conclusion is that there is an effect of financial recording training and simple financial analysis on the decision making of laying breed chicken breeders in YangapiVillage.
\end{abstract}

Keywords: accounting; financial ratio analysis; decision making

\section{PENDAHULUAN}

Pertanian dan peternakan masih menjadi sebagai sektor utama dalam lapangan usaha di daerah Bali. Salah satunya kabupaten Bangli dalam data yang diperoleh dari situs resmi Pemerintah Kabupaten Bangli, secara geografis Kabupaten Bangli terletak di tengah - tengah pulau bali, sehingga kabupaten Bangli tidak memiliki wilayah pantai. Luas wilayah
Kabupaten Bangli sebesar 520,81 Hektar atau $9,25 \%$ dari luas wilayah Provinsi Bali. Ketinggian dari permukaan laut antara $100-$ $2.152 \mathrm{~m}$, sehingga tanaman apa saja bisa tumbuh di daerah ini. 76\% lahan di Kabupaten Bangli sebagai sektor pertanian, kehutanan , serta perikanan dan peternakan.

Tembuku adalah salah satu kecamatan yang ada di Kabupaten Bangli, tepatnya di 
desa Yangapi, bertani dan berternak masih menjadi matapencaharian utama masyarakat setempat. Dalam kondisi satu tahun terakhir masyarakat mulai melakukan wirausaha di bidang peternakan ayam ras petelur, dengan tujuan dapat mengoptimalkan segala potensi sumber daya alam dan sumber daya modal yang dimiliki.

Salah satu tantangan utama yang dihadapi oleh peternak ayam petelur di Desa Yangapi adalah terkait dengan pengelolaan modal kerja serta tingkat kesehatan dalam usaha peternakan. Pengelolaan modal kerja merupakan faktor kunci keberhasilan dan kegagalan sebuah usaha, untuk mencapai hal tersebut dapat ditempuh dengan melakukan pencatatan keuangan dengan baik. Peternak memeperoleh informasi keuangan dalam membantu pengambilan keputusan. Pencatatan keuangan harus sesuai dengan transaksi yang terjadi di lapangan, untuk menghasilkan laporan keuangan yang andal.

Berdasarkan fenomena di lapangan, peternak ayam petelur dalam pelaksanaan pencatatan keuangan mengalami kesulitan karena keterbatasan pengetahuan tentang ilmu akuntansi, rumitnya proses pencatatan keuangan dan anggapan bahwa laporan keuangan bukanlah hal yang penting bagi peternak ayam petelur. Kendala yang menghambat peternak ayam petelur dalam penerapan pencatatan keuangan antara lain adalah latar belakang pendidikan, belum pernah melakukan pelatihan pembukuan dan kebutuhan akan laporan keuangan belum dirasakan perlu. Jika permasalahan tersebut tidak diatasi maka menyebabkan pengelolaan keuangan pada peternak ayam petelur tidak efektif dan efisien. Prof. Hamidah (2015) menjelaskan bahwa diperlukan adanya laporan keuangan dalam analisis manajemen terhadap operasi tahun lalu dan pengambilan keputusan mengenai prospek - prospek usaha di masa yang akan datang. Wirausaha yang memiliki literasi keuangan yang baik mampu membuat keputusan yang tepat dalam pengelolaan keuangannya guna menghadapi tantangan global yang semakin kompleks.

Berdasarkan permasalahan di atas, penulis memandang sangat mendesak untuk memberikan pemahaman dalam pencatatan keuangan dan analisa laporan keuangan sederhana. Melalui kuliah kerja nyata penulis melakukan pelatihan pencatatan keuangan dan analisa keuangan sederhana. Sehingga peternak ayam petelur dapat mencatata transaksi harian dan menyusun laporan keuangannya secara periodik.

\section{METODE}

Pengabdian kepada masyarakat ini bertujuan untuk memberikan pemahaman pencatatan transaksi keuangan dan penilaian kinerja keuangan unit bisnis pada peternak ayam ras petelur di Desa Yangapi. Metode kegiatan yang dilakukan sebagai berikut:

\section{Kegiatan I (persiapan)}

Melakukan diskusi dengan peternak di Desa Yangapi terkait dengan identifikasi pencatatan yang telah dilakukan sebelumnya serta merumuskan kebutuhan peternak terhadap laporan keuangan. Penulis juga memberikan kuesioner tahap 1 untuk mengetahui tingkat pemahaman peternat terhadap pencatatan keuangan dan laporan keuangan. Selanjutnya menentukan waktu pelaksanaan pelatihan pencatatan yang dilakukan secara daring.

Penulis menyusun kolom pada microsoft excel sebagai aplikasi pencatatan sehingga memudahkan peternak dalam mengimplementasikan pencatatan keuangan secara periodik.

\section{Kegiatan II (pelaksanaan)}

Pelaksanaan dilakukan pada 11 Februari 2021, selama 7 hari berturut - turut. Kegiatan diawali dengan penulis memberikan presentasi terkait tata cara pencatatan keuangan untuk transaksi sehari - hari, kemudian peternak secara langsung mempraktekkan menyusun neraca saldo, serta mencatat transaksi pada jurnal di microsoft excel.

\section{Kegiatan III (evaluasi)}

Evaluasi terhadap laporan keuangan peternak dan melakukan analisa sederhana menggunakan rasio keuangan, untuk menjawab kebutuhan - kebutuhan peternak pada laporan keuangan, serta memberikan kuesioner tahap 2 kepada peternak untuk mengetahui pemahaman akhir peternak setelah mendapat pelatihan dari penulis.

Target capaian dalam kegiatan ini adalah peternak dapat melakukan pencatatan keuangan serta dapat memberikan analisa terhadap penilaian modal kerja pada periode sebelumnya. Indikator keberhasilan dalam kegiatan ini, peternak dapat memahami $60 \%$ dari pemahaman terhadap teori serta praktik sesuai dengan prosedur yang penulis sampaikan dalam kegiatan pengabdian masyarakat.

\section{HASIL DAN PEMBAHASAN}

Hasil kuesioner tahap 1 yang diberikan peternak ayam petelur di daerah Yangapi 
Bangli, mengidentifikasi sebanyak 100\% peternak tidak memahami pencatatan keuangan. Dengan mengetahui pemahaman dasar yang dimiliki peternak penulis akan mengoptimalkan pada bagian - bagian yang sangat penting pada prosedur pencatatan keuangan.

Kegiatan presentasi dilakukan secara daring melalui google meet dan pendampingan pencatatan keuangan sederhana juga dilakukan secara daring melalui anydesk. Jumlah peserta diikuti oleh 6 orang peternak dan waktu pelaksanaannya selama 7 hari mulai dari tanggal 11 Februari - 17 Februari 2021 dengan durasi 60 menit setiap harinya. Adapun hal - hal yang dipraktikkan oleh peternak yaitu, pencatatan faktur transaksi, pengisian kolom tanggal, debit, dan kredit, sesuai dengan transaksi yang terjadi pada hari pelatihan.

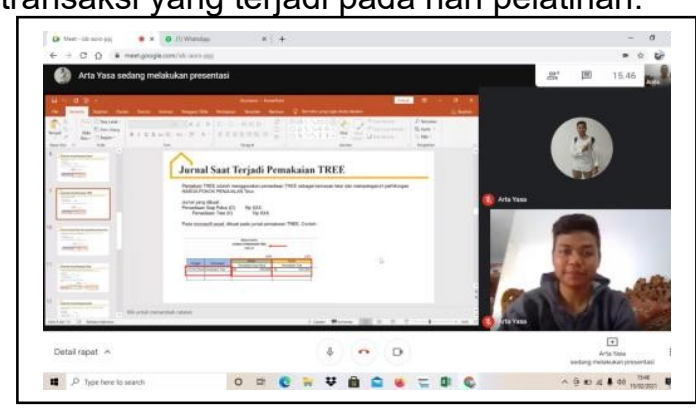

Gambar 1. Presentasi prosedur pencatatan keuangan, melalui google meet

Pencapaian dalam kegiatan pengabdian pada para peternak ayam petelur di Desa Yangapi, Bangli adalah para peternak mampu membuat pencatatan keuangan sederhana dengan persentase pencapaian $60 \%$. Adapun bentuk materi yang diberikan kepada para peternak antara lain: manfaat laporan keuangan pada usaha yang dijalankan, konsep yang ada dalam akuntansi, perhitungan harga pokok produksi, teknik pencatatan pada jurnal penjualan, jurnal penerimaan kas, jurnal pembelian, jurnal pengeluaran kas, jurnal umum, membaca laporan laba rugi, membaca laporan neraca, serta analisa rasio keuangan yang lumrah digunakan.

Pembuatan jurnal dibantu dengan microsoft excel yang telah penulis desain menyerupiai aplikasi akuntasi pada umumnya. Microsoft excel diperuntukan sebagai tools dalam pencatatan, tools ini memudahkan peternak dalam melakukan pencatatan keuangan, dengan metode single entry maka jurnal sudah dapat dibuat sesuai dengan transaksi yang terjadi. Tools ini telah didesain sesuai dengan kebutuhan peternak dalam pencatatan keuangan, dan dengan keterbatasan pemahaman akuntansi peternak tetap dapat melakukan pencatatan keuangan dan menyusun laporan keuangan.

Pengelolaan hasil kuesioner dari tahap 1 saat sebelum diadakannya pelatihan dibandingkan dengan hasil kuesioner tahap 2 setelah pelatihan yang diisi oleh para peternak mengenai pemahaman mereka tentang pencatatan keuangan sederhana, ditunjukkan dalam gambar berikut:

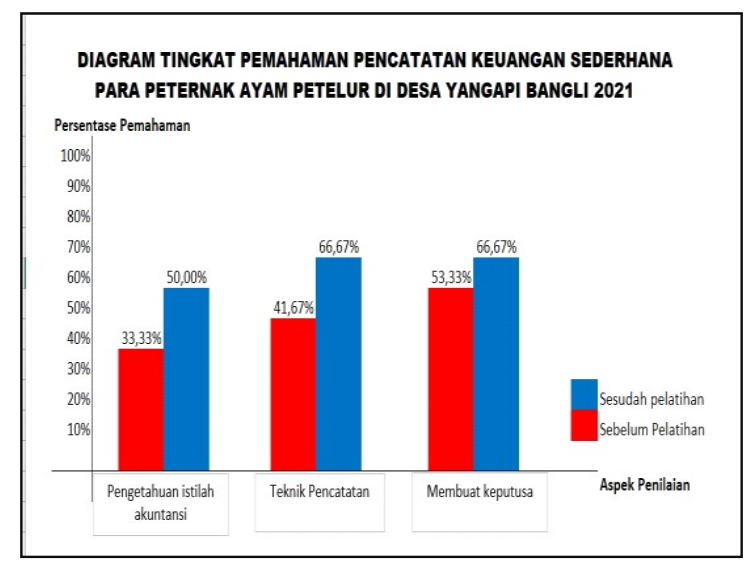

Gambar 2. Tingkat pemahaman pencatatan keuangan sederhana pada peternak ayam petelur di Desa Yangapi, Bangli.

Berdasarkan Gambar 2 di atas, dapat diketahui bahwa untuk tingkat pemahaman peternak terhadap pencatatan transaksi keuangan secara sederhana dan analisa laporan keuangan, sebagai berikut : pengetahuan terkait dengan istilah akuntansi yang semulanya $33,33 \%$ menjadi $50,00 \%$, istilah akuntansi yang dimaksud meliputi, piutang, utang, prive, harga pokok penjualan , laporan keuangan, laporan neraca, dan perubahan modal. Begitu pula terkait dengan teknik pencatatan akuntansi yang semulanya $41,67 \%$ meningkat menjadi $66,57 \%$. Teknik pencatatan ini meliputi akun debet maupun akun kredit yang tepat saat menjurnal sesuai dengan transaksi keuangan yang terjadi.

Setelah peternak memahami cara pencatatan keuangan sesuai dengan standar akuntansi, maka penulis memberikan materi kedua terkait dengan pengambilan keputusan dengan memperhitungkan hasil rasio dari laporan keuangan yang sudah dibuat.

Kebutuhan peternak terhadap laporan keuangan untuk memberikan solusi dari permasalahan apakah pengunaan modal kerja yang telah dilakukan sudah efektif atau belum.

Rasio keuangan dapat membantu para stakeholder untuk dapat membandingkan hasil keuangan suatu perusahaan dengan pesaingnya serta dapat menunjukkan suatu letak permasalahan keuangan perusahaan dan sedapat mungkin mengetahui kekuatan dan kelemahannya. Analisa rasio meliputi ; rasio 
likuiditas, manajemen aset, manajemen utang, dan profitabilitas. Prof. Hamidah (2015). Pada microsoft excel telah penulis sediakan rumus yang dapat membentuk secara otomatis nilai rasio keuangan, dari laporan keuangan yang telah di entry oleh peternak. Dengan demikian peternak dapat mengetahui rasio keuangan dengan mudah, dan peternak dapat membaca dari hasil rasio yang didapatkan.

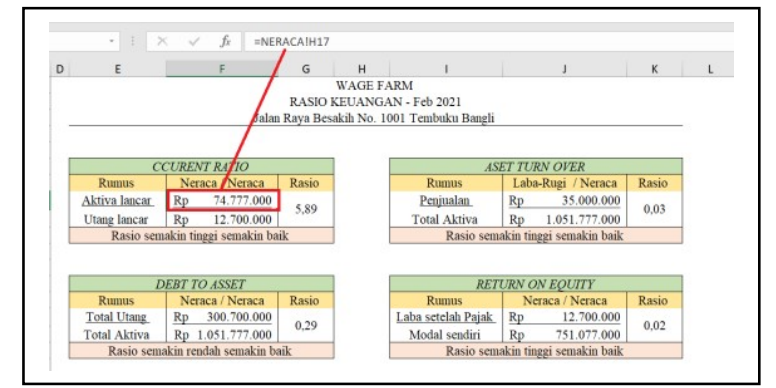

Gambar 3. Microsoft Excel - Perhitungan Rasio Keuangan milik I Nengah Wage

Dengan pendampingan yang penulis lakukan terkait pencatatan keuangan, maka diperoleh perhitungan rasio keuangan pada 6 peternak ayam petelur di Desa Yangapi diperlihatkan sebagai berikut:

Tabel 1. Hasil analisa rasio keuangan terhadap laporan keuangan

\begin{tabular}{|c|c|c|c|c|}
\hline \multirow{2}{*}{ Nama Peternak } & \multicolumn{4}{|c|}{ Rasio Keuangan } \\
\hline & Ratio & $\begin{array}{l}\text { Aset Turn } \\
\text { Over }\end{array}$ & $\begin{array}{l}\text { Debt to } \\
\text { Asset }\end{array}$ & $\begin{array}{l}\text { Return on } \\
\text { Equity }\end{array}$ \\
\hline Adisty & 4.85 & 0.03 & 0.20 & 0.01 \\
\hline Cindy & 1.18 & 0.01 & 0.23 & 0.01 \\
\hline Martika & 2.43 & 0.01 & 0.11 & 0.01 \\
\hline Wage & 5.89 & 0.03 & 0.29 & 0.02 \\
\hline Sukarnaya & 9.51 & 0.01 & 0.22 & 0.02 \\
\hline Pebrianto & 6.96 & 0.02 & 0.22 & 0.02 \\
\hline Average & 5.14 & 0.02 & 0.21 & 0.02 \\
\hline
\end{tabular}

Dari tabel 1, menujukkan rasio terhadap laporan keuangan dari peternak ayam Desa Yangapi (6 responden). Nilai rasio tersebut telah di rata - ratakan untuk meberikan gambaran penggunaan modal kerja ternak ayam petelur di Desa Yangapi secara global. Current ratio sebesar 5.14, artinya usaha ternak ayam petelur di Desa Yangapi dapat memenuhi kewajiban jangka pendek (utang pakan) dengan mudah, karena perbandingan antara aktiva lancar dan jangka pendek sebesar 5 : 1. Dari analisa current ratio tersebut digambarkan usaha ayam petelur di Desa Yangapi tetap likuid terhadap utang jangka pendek yang ditanggung usahanya. Dengan demikian peternak dapat memanfaatkan kondisi tersebut, dengan menimbun persediaan melalui pembelian kredit, sehingga peternak dapat terhindar dari fluktuasi harga yang terlalu tinggi pada waktu mendatang.

Total asset turn over, pada peternak ayam di Desa Yangapi sebesar 0,02 yang artinya seluruh aktiva dapat dimanfaatkan sebanyak 0,02 dalam memperoleh penjualan.
Nilai 0,02 terbilang tinggi, karena saat perhitungan rasio yang dilakukan penjualan

yang terhitung hanya 7 hari. Nilai rasio ini menunjukkan peternak dapat memanfaatkan aktiva dengan optimal, aktiva tersebut terdiri dari; ayam, persediaan pakan, dan kandang secara tepat sehingga dapat menghasilkan telur yang sesuai target dan pada akhirnya membuat penjualan meningkat melampui biaya perolehan aktiva yang dilakukan sebelumnya.

Total Debt to Asset atau rasio yang memperlihatkan proporsi seluruh kewajiban yang dimiliki peternak dalam usahanya berbanding dengan seluruh kekayaan pada usaha tersebut. Pada hasil rasio yang penulis lakukan mendapatkan nilai 0,21 , yang artinya rasio utang terhadap aktiva terbilang rendah, karena setiap unit usaha diperbolehkan maksimal memiliki utang sebesar $60 \%$, sedangkan pada usaha ternak ayam di Desa Yangapi nilai yang ditunjukkan sebesar $21 \%$, ini mencerminkan rendahnya resiko kredit macet pada usaha ternak ayam petelur di Desa Yangapi. 
Kemampuan usaha dalam memperoleh laba untuk mengembalikan penanaman modal yang dilakukan ditunjukan dalam analisa rasio return on equity, pada usaha ternak ayam di Desa Yangapi, nilainya adalah 0.02. Profitabilitas pada usaha ternak ayam petelur di Desa Yangapi memiliki pengembalian modal yang baik terhdap peternak atau pemegang saham.

Dapat disimpulkan dari empat rasio tersebut usaha ternak ayam petelur di Desa Yangapi dalam keadaan sehat, dan pengelolaan modal kerja dilakukan efektif dan efesien, terbukti dari usaha ternak ayam petelur dapat memenuhi kewajiban jangka pendek dengan mudah, pemanfaatan seluruh aktiva sangat baik dalam memperoleh penjualan, dan utang yang ditanggung terbilang rendah sehingga menimbulkan risiko kredit yang rendah pula, serta pengembalian penanaman modal yang diterima dari penjualan cukup tinggi.

\section{SIMPULAN DAN SARAN Simpulan}

Dari hasil pengabdian yang penulis lakukan pada peternak ayam petelur Desa Yangapi terkait dengan pencatatan keuangan serta penilaian modal kerja menggunakan analisa rasio keuangan. Peternak dapat melakukan pencatatan keuangan dengan baik dan dalam pengambilan keputusan bersifat hati - hati dengan memperhitungkan laporan keuangan yang telah disusun. Persentase pencapaian sebesar $66,67 \%$ nilai ini sudah baik sesuai dengan target awal penulis sebesar $60 \%$, mengingat pencatatan keuangan masih sangat awam dilakukan pada peternak ayam di Desa Yangapi. Dengan keterbatasan waktu dan komunikasi yang dilakukan secara daring, menyulitkan penulis dalam menyampaikan materi secara keseluruhan dengan baik. Secara umum peternak dapat menerima dengan baik pemahaman yang penulis berikan, akan tetapi pengetahuan terkait dengan literasi - literasi keuangan juga terus diperkaya diperoleh dari berbagai sumber.

\section{Saran}

Untuk mahasiswa yang akan melakukan kegiatan kuliah kerja nyata di Desa yangapi dan melakukan penelitian yang sama dengan penulis, diharapkan dapat menlanjutkan sampai pendampingan terkait dengan perpajakan serta pengembangan aplikasi akuntansi yang lebih modern dan kompleks.

\section{UCAPAN TERIMAKASIH}

Penulis selalu beryukur kepada Tuhan
Yang Maha Esa telah diberikan keselamatan dalam proses kegiatan kuliah kerja nyata di Desa Yangapi, serta arahan dari Ibu Eviani selaku dosen pembimbing serta para paternak ayam petelur di Desa Yangapi, dengan antusias dalam pelatihan yang diberikan.

\section{DAFTAR RUJUKAN}

Aburrahman, F. I.H, Sukaris, \& Andi, R., R, dkk. (2020). Pelatihan Dan Pembuatan Sistem Laporan Keuangan Sederhana Pada Koperasi Wanita Desa Sonoadi. DedikasiMU :Volume 2, Nomor 2, Juni 2020.

Badan Pusat Statistik, 2020. Data Pendapatan Masyarakat Desa Yangapi. Tersedia pada : https://banglikab.bps.go.id/ (diakses pada 3 Februari 2021).

Della Ayu Zonna Lia, Rustam Hidayat, Zahroh

Z.A. (2014). Penilaian Kinerja Keuangan Pada Usaha Kecil Dan Menengah Berdasarkan Analisa Rasio Keuangan. Malang, Universitas Barawijaya.

Margunani, Inaya S., M. \& Ahmad, S. (2020). Pelatihan Pencatatan Keuangan Sederhana UMKM Intip Di Desa Nyatnyono Ungaran Semarang. PARINATA_ABADI : Jurnal Pengabdian Kepada Masyarakat.

Nina, H. \& Hari, S. (2017). Pelatihan Dan Pembuatan Laporan Keuangan Kepada Pengusaha UMKM Di Kecamatan Karangrejo Kabupaten Tulungagung. J- ADIMAS : Jurnal Pengabdian Kepada Masyarakat. Volumen 5, Nomor 1.

Prof. Dr. Hamidah, SE.,M.Si. (2018). Manajemen Keuangan. Yogyakarta: Mitra Wacana Media.

Rahmawati, \& Andika, R. (2020). Pelatihan Dan Pembuatan Sistem Laporan Keuangan Sederhana Pada UMKM Di Kota Palopo. Jurnal Akuntansi : Vol. 03, No 01 Februari.

Suparman, A. \& Feby, I. dkk. (2020). Pelatihan Pembukuan Sederhana Bagi Pelaku Usaha Kerajinan Anyam Mendong Di Kecamatan Rajapolah Kabupaten Tasikmalaya. Jurnal tidak diterbitkat.

Wilfried, S. M., \& Frendy A. O. P. (2018). Pelatihan Penyusunan Laporan Keuangan Dengan Teknik Pembukuan Sederhana Bagi Pelaku Usaha UMKM Di Kecamatan Malayayang Kota Manado Provinsi Sulawesi Utara. Jurnla Administrasi Bisnis : Vol 7. No. 2. 2018. 